\title{
A dynamic model for predicting the falling number of rye grains in Finnish (Ostrobothnian) conditions
}

\author{
Leena Laurila, Tuomo Karvonen and SirkKa-Lissa Hitvola
}

\begin{abstract}
LAURILA, L., Karvonen. T. \& HiIVola, S.-L. 1992. A dynamic model for predicting the falling number of rye grains in Finnish (Ostrobothnian) conditions. Agric. Sci. Finl. 1: 57-71. (Univ. Helsinki, Dept. Crop Husb., SF-00710 Helsinki, Finland and Agric. Res. Centre of Finland, South Ostrobothnia Res. Sta., SF-61400 Ylistaro, Finland).
\end{abstract}

This study was carried out with two primary goals in mind. Firstly, the purpose was to study the behaviour of the falling number of rye during the growing season in South Ostrobothnia. Secondly, the aim was to study the effect of air temperature and precipitation on the falling number and to develop a mathematical model for predicting the daily changes in the falling number of rye.

Falling number data was collected at the Research Station of South Ostrobothnia of the Agricultural Research Centre in 1975-1987. The varieties used in the study were Anna, Hankkija's Jussi, Sampo, Toivo and Voima.

On the basis of the falling number measurements and the daily weather data, a dynamic model for predicting the daily changes in falling number of rye was designed. The most important independent variables of the model are maximum air temperature and precipitation.

The dynamic model predicted most accurately the falling number of the variety Anna. The coefficient of determination was 0.81 . The lowest coefficient of determination was 0.70 for the varieties Sampo and Toivo.

The maximum falling number was high in the years with warm periods during the maturing of the kernel. The threshold was $23^{\circ} \mathrm{C}$. In these years the dynamic model was not capable of predicting the highest falling number. Moreover, the predicted decrease in the falling number was usually faster than the measured one.

The low falling numbers in South Ostrobothnia were mostly not due to low maximum falling number but to the fact that the maximum was reached early at the milk ripening stage, and at that moment rye was too moist to be harvested. After the maximum was reached, the falling number started to decrease due to precipitation and/or temperature.

Key words: rye, falling number, amylase activity, mathematical model, weather

\section{Introduction}

Due to unfavourable weather conditions at harvest time, ear-sprouting and low falling numbers are common for rye in Finland. Therefore the duration of the falling number and the right balance of dormancy in maturing rye kernels are important. At harvest time, autumn rains constitute a very important risk for rye quality, especially starch quality, which the falling number measures.

At the early stage of the ripening process, soon after inflorescence, when the moisture content of the rye grain is $60-70 \%$, the falling number is very low. Consequently, the alpha-amylase activity is high (Olered and Hummel-Gumaelius 1966, Olered 1967, Hrtze 1969, Rohrlich and Hitze 1969). Thereafter the falling number increases quickly and peaks at a $50 \%$ moisture content, 
which is the milk ripe stage of the grain. After this the falling number begins to decrease slowly. The presence of large fluctuations in the falling number not showing, however, in the alpha-amylase activity is a characteristic of this decrease. OLERED (1976) points out that these fluctuations are an internal phenomenon of the grain and they should not be confused with germination. The falling number continues to decrease when the grain moisture content falls from 40 to $20 \%$. The decrease ceases when the grain moisture content is less than $20 \%$ (RoHrLich and Hrtze 1969). The alpha-amylase activity increases quickly, or the falling number decreases quickly during the ripening process once the enzymes have been activated (OLERED 1963). The falling number of rye may decrease to a low level even before the grain reaches the yellow ripe stage in unfavourable weather conditions.

According to BELDEROK (1968) the dormancy can be divided into two phases: an immediate postharvest phase in which practically no grains germinate in the germination test, and a subsequent transitional phase following the after-ripened state in which dormancy ends in gradually increasing number of grains. The rye grain is in dormancy when it becomes capable of germinating, which takes place a few weeks after fertilization. The dormancy may last up to maturity or even past it, or it may break already at the milk ripe stage of the grain. The genetic properties of the variety and weather have an effect on the ending of dormancy. High temperature shortens the dormancy of grains and may thus cause a drop in an already high falling number if it rains.

Sprouting in the ears is associated with the ending of dormancy. Sprouting capacity and sufficient moisture content are prerequisites for sprouting to begin (ROHRLICH and HITZE 1969). ROHRLICH and HITZE (1969) noticed that rye had a low sprouting capacity at a $50 \%$ moisture content. The sprouting capacity increases when the ripening of the grain proceeds and the moisture content decreases. According to LALLUKKA (1976), sprouting may take place immediately after or even before ripening in some varieties grown in Finnish conditions. In her experiments the end of dormancy, measured by the drop in falling number, was close to the date of yellow ripening.

Rain has only an insignificant effect on the moisture content of the grain at the early ripening stages of the grain and therefore affects the falling number only at the late ripening stage of the grain. A certain moisture content of the grain is needed for changes in the activity of the enzymes to occur and a certain minimum value must be exceeded for amylase to be activated (FRÖMAN 1976). According to OLERED (1967), this value lies is around 25-328 $\%$. Olered and Hummel-Gumaelius (1966) found a negative correlation between the rainfall and the falling number. In HuMMEL-GuMAELIUS (1982) study temperature had a greater effect on the falling number at the early stage of ripening than did rainfall. At the yellow ripening stage rainfall becomes more important than temperature. If the weather is dry during the late ripening stage of the grain, the falling number of the early ripening stage is maintained. If the weather is moist, it may result in a decrease in the falling number (FRÖMAN 1976).

According to FRÖMAN (1976), the amylase activity at the early ripening stage is conrolled partly by temperature dependent conditions, where high temperatures initiate high falling number and low temperatures result in low falling number. He noticed on the basis of FAGERBERG'S (1966) and LUNDEGREN'S (1967) studies that there is a certain connection between the curves of the temperature and the falling number. There is however, a delay of three days in the minimum and maximum values of the falling number according to the temperature. Hummel-Gumaelius (1982) observed a high positive correlation between the temperature prevailing weeks before the harvest and the falling number. He did not get a significant difference in the effect between maximum and average temperatures of the day. The temperature during four weeks before harvest gave a better correlation than the temperature during shorter periods. VARIS et al. (1983) found a positive correlation between the falling number and the temperature sums that were measured at ten-day intervals backwards from 
harvest time. The temperature sum I (1-10 days backwards from harvest) gave a correlation coefficient of 0.55 , the temperature sum II (10-20 days backwards from harvest) gave 0.52 and the temperature sum III (20-30 days backwards from harvest) gave a correlation coefficient of 0.50 . They also observed that the falling numbers were high if there was a warm period of average daily temperature over $15^{\circ} \mathrm{C}$ before harvest.

Because the quality of rye fluctuates remarkably from year to year and weather has a distinct effect on the quality, the agricultural advisory organizations have developed a falling number service to enable farmers to get information about the level of falling number and when the risk of sprouting is most probable. Though, there are problems in this system; the number of sampling localities is too small, and there is a delay of about two days before the results of the falling number are reported. As known, the falling number of rye can change dramatically in a couple of days. In addition, the ripening process of rye varieties vary depending on locality and microclimatic factors.

The purpose of our work was to obtain information of the possibilities to predict the falling number at different maturing stages of rye. In addition to this, we wanted to get more exact information as to what climatic factors determine the level of the falling number.

\section{Material and methods}

\section{Test material}

The results of the harvest time trial in rye carried out at the Research Station of South Ostrobothnia of the Agricultural Research Centre were used as test material. The Research Station is located at the latitude $63^{\circ} \mathrm{N}$. The material was collected in 19751987. Three different harvest times were included in the trial. The first harvest was done a few days after the yellow ripening stage, which is considered the normal harvest time. The second threshing was done about a week, and the third one about a week later than the second. In addition to this material, the data measured for the falling number service in 1977-1986 was used. The falling number was measured at two to four day interval, and the measurements were started at a $50 \%$ moisture content, which is approximately the milk ripening stage of the grain.

The varieties investigated were Anna, Hankkija's Jussi, Sampo, Toivo and Voima, of Finnish origin. The observations of three varieties, Hankkija's Jussi, Sampo and Voima, covered all 13 test years, those of Anna 12 years, the missing year is 1977, and Toivo was evaluated in 1975 through 1983.

The variety Anna is characterized as a highyielding, large grained late variety. Because of the large grain size, the grains dry slowly. The falling number is quite low when harvested at normal harvest time. Hankkija's Jussi has a short and strong straw, and small grains. The duration of the falling number is slightly better than that of other varieties; otherwise its falling number represents the average. Sampo is a small grained variety with a long straw. Its falling number is considered to be good. Toivo is an old variety. It has the characteristics of a native variety of rye with small grains and a long and weak straw. The falling number is high, but it falls quickly. Voima is a high-yielding variety with medium-size grains, but susceptible to lodging. Its falling number represents the average. The earliest of these five varieties are Toivo and Sampo and Anna is the latest.

\section{Description of the model}

The basic idea of the model is to divide the growing season into three periods:

1) the falling number increases, but dormancy is not achieved

2) dormancy

3) the period after dormancy is broken.

Researchers have different opinions as to when the filling of the endosperm begins. The estimates lie between 7-21 days after heading. According to WOODMAN and ENGLEDOW (1924), the filling of the endosperm begins 21 days after heading. In the prediction model of this study the first period was 
assumed to start 14 days after heading. During this period the effective temperature sum $\mathrm{E}_{\mathrm{TS}}$ is accumulated and the falling number starts to rise.

The second period, dormancy, starts when the accumulated temperature sum reaches a critical temperature sum $\mathrm{E}_{\mathrm{TS}, \mathrm{CR} \text { IT }}$. At this point, another temperature sum, $\mathrm{D}_{\mathrm{TS}}$, starts to rise. The basic assumption of this study is that the second period

Table 1. Independent and dependent variables and model parameters.

Independent variables:

I Day of the year (1..365)

$\mathrm{I}_{\mathrm{HEAD}} \quad$ Date of heading

$\mathrm{I}_{\mathrm{FINAL}} \quad$ The last day of computation

$P_{1} \quad$ Precipitation $(\mathrm{mm})$ on day I

$\mathrm{T}_{14} \quad$ Mean air temperature $\left({ }^{\circ} \mathrm{C}\right)$ on day $\mathrm{I}$

$\mathrm{T}_{1, \mathrm{M}} \quad$ Maximum air temperature on day I

$T_{M, L A G} \quad$ Change in maximum air temperature on day $\mathrm{I}$ and day I-LAG $\left(T_{L, M}-T_{1-L A G, M}\right)$

Dependent variables:

$\mathrm{E}_{\mathrm{TS}} \quad$ Effective temperature sum computed either from sowing or heading (degree days)

$\mathrm{D}_{\mathrm{TS}} \quad$ Accumulated temperature sum during dormancy (degree days)

$F_{1} \quad$ Falling number for daynumber $\mathrm{I}$

\section{Model parameters:}

$\mathrm{T}_{\mathrm{ETS}} \quad$ Base temperature for computing effective temperature sum $\left(5^{\circ} \mathrm{C}\right.$ was used)

$\mathrm{T}_{\text {DORM }} \quad$ Base temperature for computing accumulated temperature during dormancy $\left(12.5^{\circ} \mathrm{C}\right.$ proposed by BELDEROK (1968)for spring wheat, but $5{ }^{\circ} \mathrm{C}$ was used in this study)

$\mathrm{T}_{\mathrm{FALL}} \quad$ Critical temperature for computing the daily change in falling number due to maximum air temperature.

$\mathrm{E}_{\mathrm{TS}, \mathrm{CRT}}$ Critical temperature sum (above $\mathrm{T}_{\mathrm{ETS}}$ ) required for dormancy to begin

$\mathrm{D}_{\text {TS,DoRM }}$ Dormancy is assumed to be broken when this critical accumulated temperature (above $\mathrm{T}_{\text {DORM }}$ ) is reached.

$\mathrm{p}_{\mathrm{M}} \quad$ Parameter for maximum temperature

$\mathrm{p}_{\mathrm{MA}} \quad$ Parameter for additional increase in falling number

$p_{D} \quad$ Parameter for change in maximum temperature

$\mathrm{P}_{\mathrm{PD}} \quad$ Parameter for precipitation after dormancy is broken

LAG Number of days - lag - between maximum temperature and falling number (see FrōMAN 1976). ends when the critical accumulated temperature sum $\mathrm{D}_{\text {TS,DORM }}$ is exceeded. The base temperature used was $5.0^{\circ} \mathrm{C}$.

During the third period, dormancy is broken and the critical factor is assumed to be the accumulated precipitation sum: the higher the precipitation, the higher the risk of sprouting. Air temperature is assumed to have a minor influence on the falling number during this period.

The flow-chart of the model is given in Fig. 1, including all the necessary equations of the model. Explanations for the independent and dependent variables and model parameters are given in Table 1.

\section{Computation of the falling number before dormancy is broken}

In the model, the falling number on day $\mathrm{I}_{\mathrm{F}}$, starts to increase 14 days after the date of heading. During the first and second periods (dormancy), the dynamic model is based on the idea that the predicted falling number of a day I is computed from the following four components (see also Fig. 1):

1) The predicted falling number $F_{I-1}$, i.e. the falling number on the previous day

2) Increase or decrease of falling number due to maximum air temperature $T_{1, M}$ (increase if above $\mathrm{T}_{\mathrm{FALL}}$, and otherwise decrease $): \mathrm{p}_{\mathrm{M}} \cdot\left(\mathrm{T}_{\mathrm{I}, \mathrm{M}}-\mathrm{T}_{\mathrm{FALL}}\right)$

3) Additional increase of falling number if maximum air temperature exceeds a certain threshold value ( $23 \mathrm{oC}$ was chosen in this study): $\mathrm{p}_{\mathrm{MA}} \cdot\left(\mathrm{T}_{\mathrm{L}, \mathrm{M}}-23\right)$, if $\mathrm{T}_{\mathrm{L}, \mathrm{M}}>23^{\circ} \mathrm{C}$.

4) Increase or decrease of falling number due to change in maximum temperature on the previous days (number of days given by parameter LAG): $p_{D}$ * $T_{M, L A G}$. The effect of this component is positive if $\mathrm{T}_{\mathrm{M}, \mathrm{LAG}}$ is positive and otherwise negative $\left(\mathrm{T}_{\mathrm{M}, \mathrm{LAG}}=\right.$ $\left.\mathrm{T}_{\mathrm{L}, \mathrm{M}}-\mathrm{T}_{\mathrm{I}-\mathrm{LAG}, \mathrm{M}}\right)$

The purpose of the first component is obvious: a day's falling number must be quite close to the previous days value if the seed is still in dormancy. The second component is based on the assumption that if dormancy is not broken, the balance between 


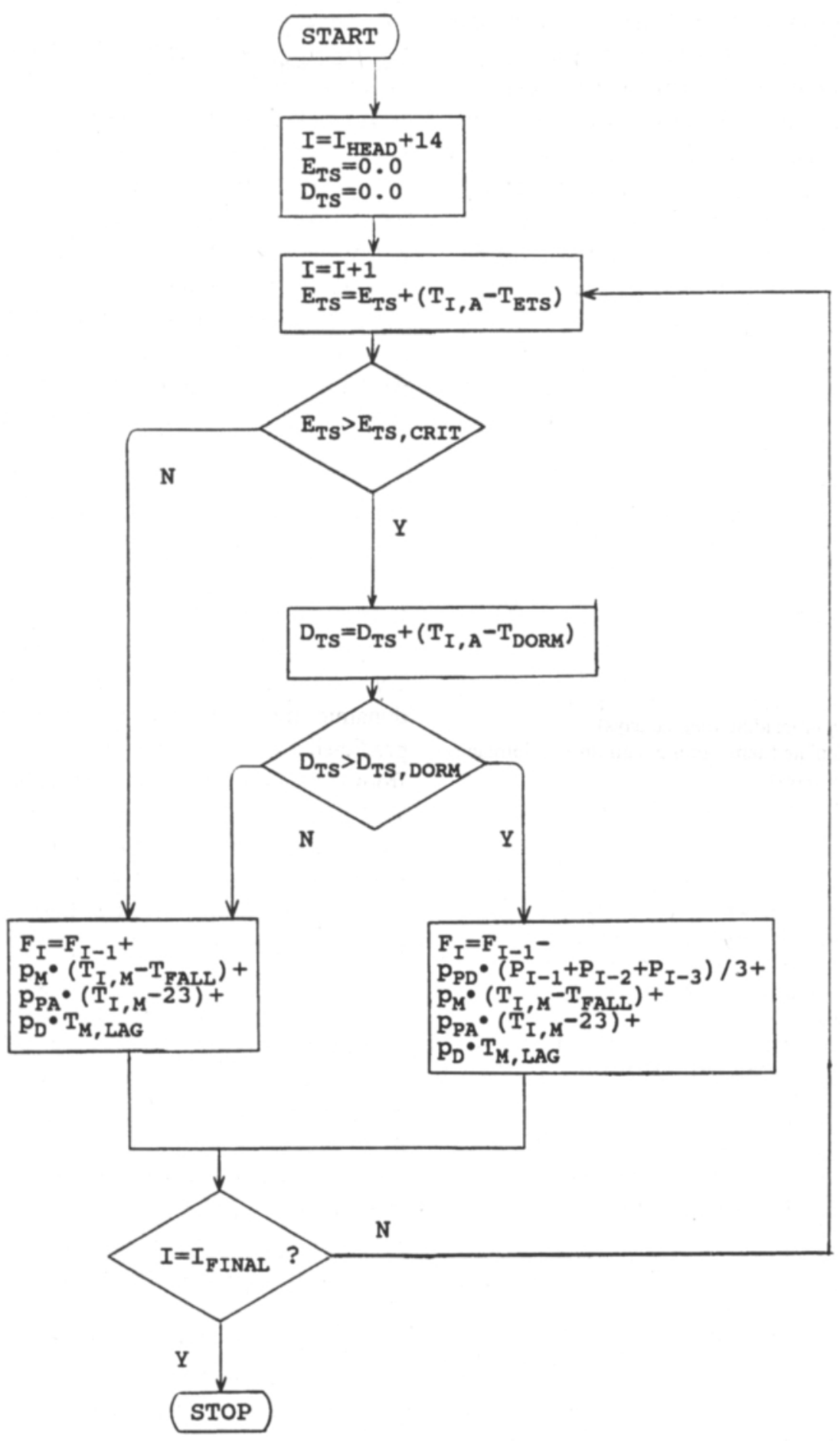

Fig 1. Flowchart of the model for predicting the falling number. 
sugars and starch is to a great extent controlled by the maximum air temperature. According to the falling number measurements carried out at the Research Station of South Ostrobothnia, a higher level of falling number can be reached if the maximum air temperatures are above $22-25^{\circ} \mathrm{C}$. The third component induces an additional increase in the falling number if the maximum air temperature is above $23^{\circ} \mathrm{C}$. The fourth component is based on FrÖMAN's (1976) observation of FAGERBERG's (1966) and LuNDEGREN's (1967) studies that the shape of the maximum air temperature curve and that of the falling number are very similar but there is a time lag of 3 days between these curves.

\section{Computation of the falling number after dormancy is broken}

The present version of the model assumes that after dormancy is broken, the falling number $F_{1}$ is computed using the same components as described above and an additional fifth component is adopted that takes into account the influence of precipitation:

5) Decrease in the falling number due to precipitation during the last two days: $\mathrm{p}_{\mathrm{D}} *\left(\mathrm{P}_{\mathrm{I}-1}+\right.$ $\left.\mathrm{P}_{1-2}\right) / 2$.

The number of previous days was arbitrarily chosen to be two, but any other number of days could also be used. The fifth component is based on the assumption that alpha-amylase activity starts to increase if it rains a lot before harvesting, and dormancy is already broken. An increase in alphaamylase activity implies a decrease in the falling number.

\section{Results and discussion}

\section{Testing of the model}

The suggested dynamic model was tested against the falling number measurements of varieties Hankkija's Jussi, Sampo, Voima, Toivo and Anna. The parameters for all varieties were estimated by an automatic method described by KARVONEN (1990). The optimized parameters are shown in Table 2 .

As seen in Table 2, the parameters varied with the variety. Parameter $\mathrm{E}_{\mathrm{TS}, \text { CRIT }}$ was the critical temperature sum which was required for dormancy to begin. The higher the value, the later dormancy began. In principle, the values varied with the earliness of the variety. The early varieties Toivo and Voima had significantly lower values than the late variety Anna. Hankkija's Jussi was an exception to this rule, but it is considered to have a good duration of falling number.

Parameter $\mathrm{D}_{\text {TS,DORM }}$ indicated the length of dormancy. The higher the value, the longer the dormancy. The differences between varieties seemed to be small. For example, a difference of 20 units meant a difference of two days in the duration

Table 2. Estimated parameters for different varieties.

\begin{tabular}{lrrrrr} 
& Jussi & $\begin{array}{c}\text { Variety } \\
\text { Sampo }\end{array}$ & Voima & Toivo & Anna \\
\hline $\mathrm{E}_{\text {TS,CRIT }}$ & 460 & 385 & 419 & 383 & 452 \\
$\mathrm{D}_{\text {TS,DORM }}$ & 72.7 & 67.8 & 61.4 & 83.4 & 76.0 \\
$\mathrm{~T}_{\text {FALL }}$ & 17.3 & 15.2 & 14.1 & 14.7 & 17.1 \\
$\mathrm{P}_{\mathrm{M}}$ & 0.51 & 0.37 & 0.29 & 0.43 & 0.40 \\
$\mathrm{P}_{\text {MA }}$ & 0.043 & 0.073 & 0.064 & 0.071 & 0.212 \\
$\mathrm{LAG}$ & 3 & 3 & 3 & 3 & 2 \\
$\mathrm{p}_{\mathrm{D}}$ & 0.057 & 0.030 & 0.073 & 0.139 & 0.159 \\
$\mathrm{P}_{\mathrm{PD}}$ & 3.83 & 2.82 & 3.53 & 3.77 & 3.60 \\
\hline
\end{tabular}


of dormancy. BENGTSSON (1975) found that the differences in the duration of dormancy were small between rye varieties. Rye is commonly considered to have a short dormancy, which was confirmed in this study. On the contrary, FröMAN (1976) pointed out that the early varieties have a shorter dormancy than the late ones. This was not observed in the present material.

If $\mathrm{E}_{\mathrm{TS}, \text { CRIT }}$ and $\mathrm{D}_{\mathrm{TS}, \mathrm{DORM}}$ are summed up, a temperature sum is obtained after which the precipitation affects the falling number. The temperature sum of the variety Hankkija's Jussi was the highest, 532.7, followed by Anna, 528.0. The temperature sums of the other varieties were under 500, 452.8 for Sampo, 466.4 for Toivo, and 480.4 for Voima. If the temperature sum of Hankkija's Jussi is ignored, the sum was dependent on the earliness of the variety. The falling number resistant variety Hankkija's Jussi had the highest value. Thereby precipitation started to affect the falling number of that variety later than that of the other varieties.

Parameter $\mathrm{T}_{\mathrm{FALL}}$ was the critical temperature for computing the daily change in falling number due to maximum air temperature. The higher the value, the higher the maximum air temperature was needed to increase the falling number. As seen in Table 2, the values of the early varieties Toivo and Sampo were lower than that of the late variety Anna. Hankkija's Jussi is quite an early variety but its value was close to Anna's value. The early varieties, e.g. Toivo and Sampo, are characterized by higher falling numbers compared to later varieties, e.g. Anna. The early varieties seemed to benefit more from the warm periods early in the summer, as noticed by FröMAN (1976). This was seen in the maximum values of the falling number.

Parameters $\mathrm{p}_{\mathrm{M}}, \mathrm{p}_{\mathrm{MA}}$ and $\mathrm{p}_{\mathrm{D}}$ indicated the change in the falling number due to maximum air temperature and changes therein. The higher the value, the greater the effect of temperature and consecuent changes in the falling number. There were no great differences between varieties in the maximum temperature, $\mathrm{p}_{\mathrm{M}}$. On the contrary, the additional increase in falling number, $\mathrm{p}_{\mathrm{MA}}$, of the variety Anna is significantly higher than those of the other varieties. It seemed that the late and high-yielding Anna benefited from the high maximum temperatures. The changes in maximum temperature of the varieties Anna and Toivo are higher than those of other varieties.

Parameter $\mathrm{p}_{\mathrm{PD}}$ indicated the effect of precipitation on the falling number after the dormancy was broken. The higher the value, the faster the precipitation reduced the falling number. The values of the varieties are quite similar. The effect of precipitation on the falling number was high. For instance, a rain of $30 \mathrm{~mm}$ in two days caused a decrease of 80-115 units in the falling number. A strong connection between precipitation and decrease in falling number has been observed in many studies (Olered and Hummel-Gumaelius 1966, Fröman 1976, Hummel-Gumaelius 1982, VARIS et al. 1983). FRÖMAN (1976) pointed out that the moisture content of the grain has to exceed a certain value before amylases are activated. In the light of the results the rain had to be heavy enough or to last long before falling number started to decrease highly.

The dynamic model predicted the falling number most accurately for the variety Anna, with a coefficient of determination of 0.81 . The second highest coefficient was for Hankkija's Jussi, 0.75, followed by Voima, 0.71 , and Sampo and Toivo, 0.70 (Figs. 2-6).

The ten years of the testing of the dynamic model can roughly be divided into two groups. Firstly, the years when the maximum falling number reached a high level, over 170. Secondly, the years when the maximum falling number was about 130 or below.

The maximum falling number was high in 1980 and 1986. According to Figs. 7 and 8, the falling number increased to a high level during the milk ripening stage, and after the maximum value was reached, the falling number started to decrease quickly. The increase in the falling number was caused by warm periods during the milk ripening stage, when the maximum air temperature was over $23^{\circ} \mathrm{C}$. Also Hummel-Gymaelius (1982) and Varis 


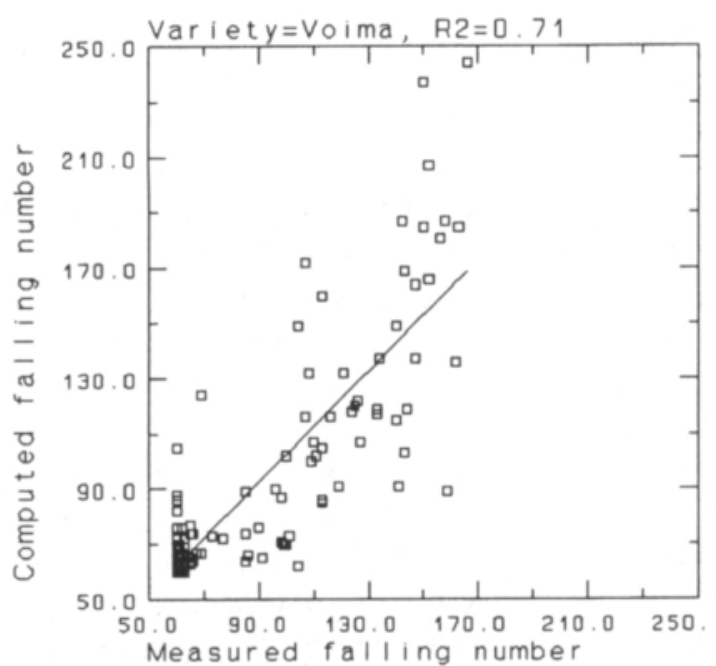

Fig. 2. Measured versus computed falling number for variety Voima.

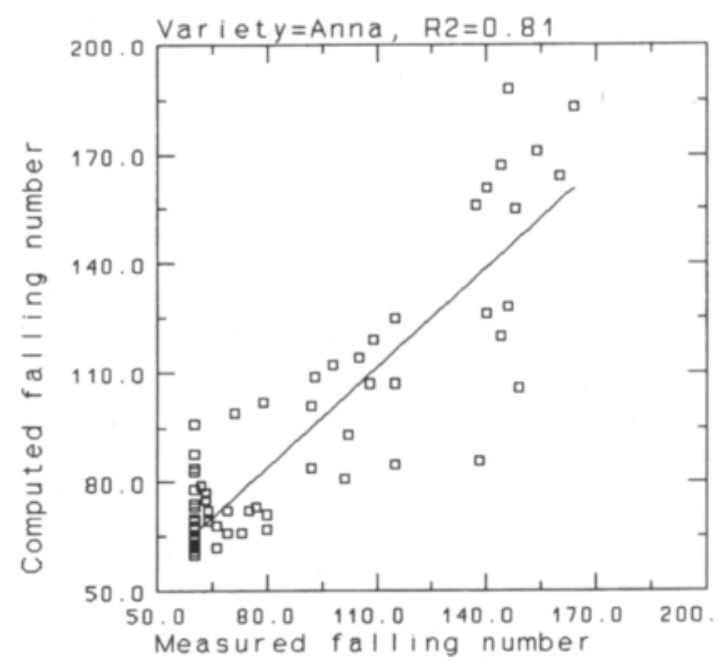

Fig. 4. Measured versus computed falling number for variety Anna.

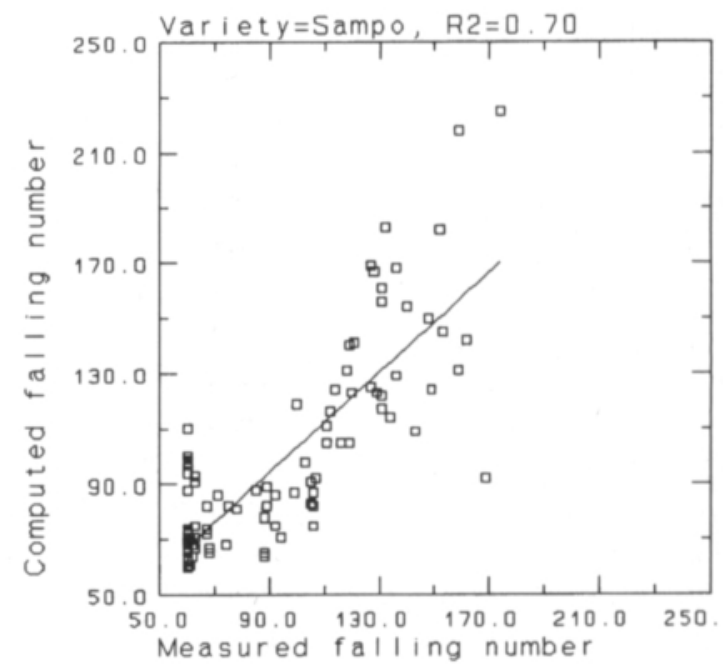

Fig. 3. Measured versus computed falling number for variety Sampo.

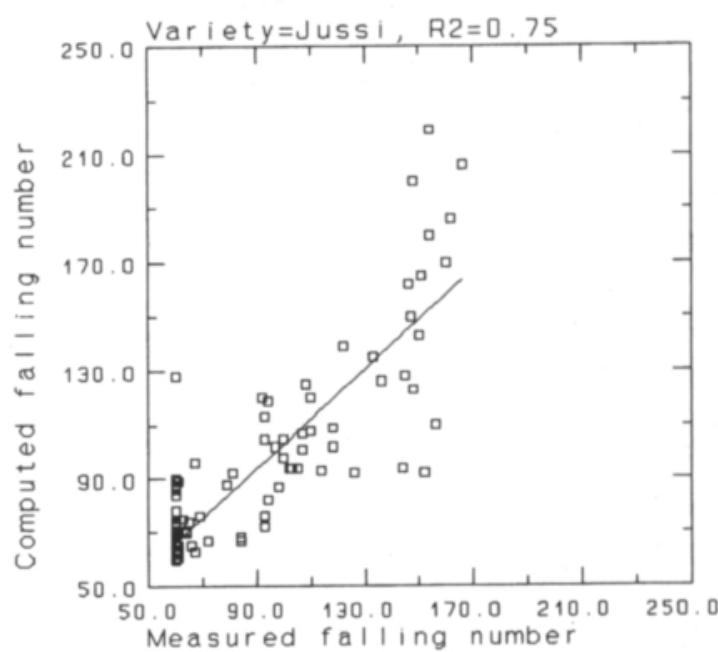

Fig. 5. Measured versus computed falling number for variety Jussi. 


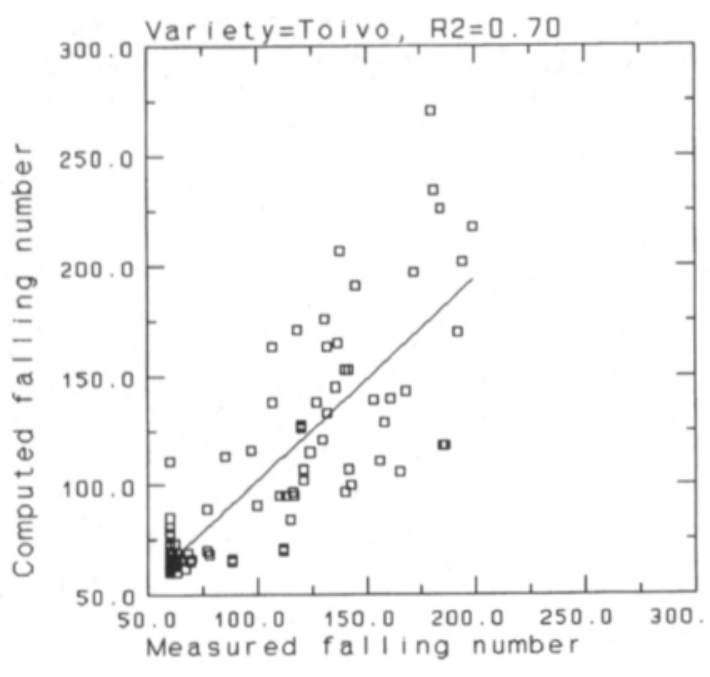

Fig. 6. Measured versus computed falling number for variety Toivo.

et al. (1983) have noticed that high temperatures increase the falling number. The warm period lasted from a few days to more than a week. In addition to high falling number, the warm period induced short dormancy. The quick drop of the falling number was mainly due to precipitation. It rained a lot during one day, or the rain lasted several days, and this caused the drop. The moisture content of the kernel seemed to exceed a certain value before the falling number started to decrease. Also Fröman (1976) has noticed this. Very often the falling number started to fall, after the maximum air temperature had decreased. During some years it was even frost at that time. It seems that the relative humidity of the air would be a better variable for the model than precipitation, because the changes in alpha-amylase activity are linked with the grain moisture content and the relative humidity of the air.

The dynamic model did not predict the highest values of the falling number. This can be seen e.g. in Figs. 7 and 8.

The fluctuations of the falling number could clearly be seen in the measurements. These fluctuations were especially great in 1983, when the falling number was high (see Fig. 9). The dynamic model was not capable of predicting these fluctuations very accurately. OLERED (1967) pointed out that the falling number of rye never stabilizes. It is typical for the development of the kernel that a dynamic balance exists between alpha-amylase and starch. The regulation of the water balance is a part of it. According to OLERED, temperature and precipitation strengthen these fluctuations. When the weather data was studied more closely it could be seen that during the change in the falling number there was a change in temperature, too, or it was raining. Naturally, part of the fluctuations can be explained by mistakes in sampling.

1977 was a year when the maximum falling number was less than 130. During the growing season the weather was unusually cool and the effective temperature sum was less than $1000 \mathrm{dd}$. The maximum value of the falling number did not reach a high level (Fig. 10). There was no very warm period during the maturation of the rye. Even the heading occurred later than usual. It can be assumed that alpha-amylase was not inactivated. Even though the falling number did not reach a high level, the falling number started to decrease after the maximum was reached, and the decrease was very fast.

In most years the low falling numbers in South Ostrobothnia were not due to low maximum values of the falling number but to the fact that the maximum value was reached early in the milk ripening stage and at that moment the rye was too moist to be threshed. After the maximum value was reached, the falling number started to decrease mainly because of the precipitation.

It was typical of the dynamic model that it assumed the decrease in falling number to occur more quickly than it did according to measurements. A reason for this is that the model ignored the fact that the effect of the precipitation on the falling number is dependent on the temperature. When it is warm, higher precipitation is needed to raise the moisture content of the kernel than when it is cool. 

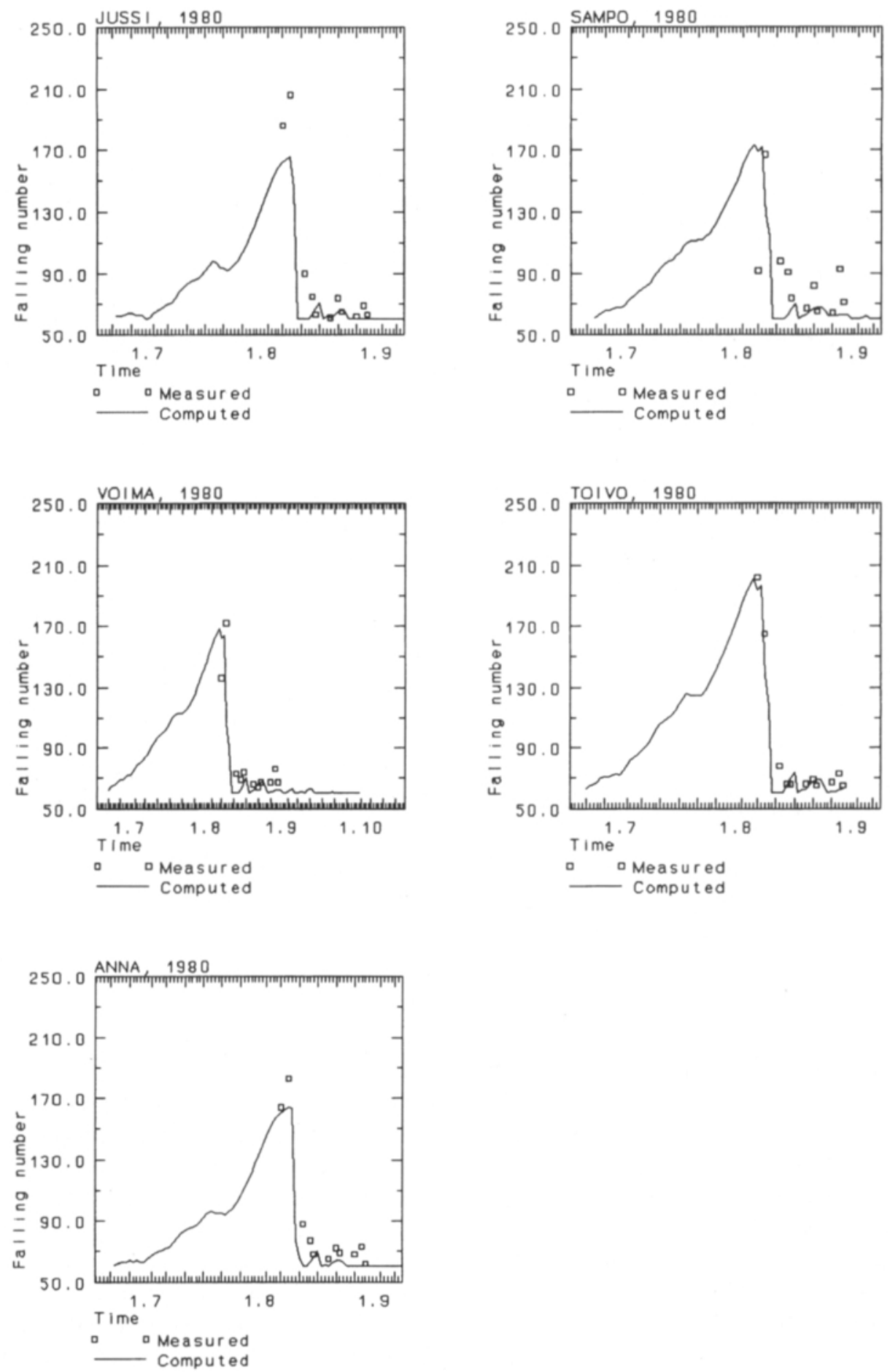

Fig. 7. Measured and computed falling number for year 1980. 

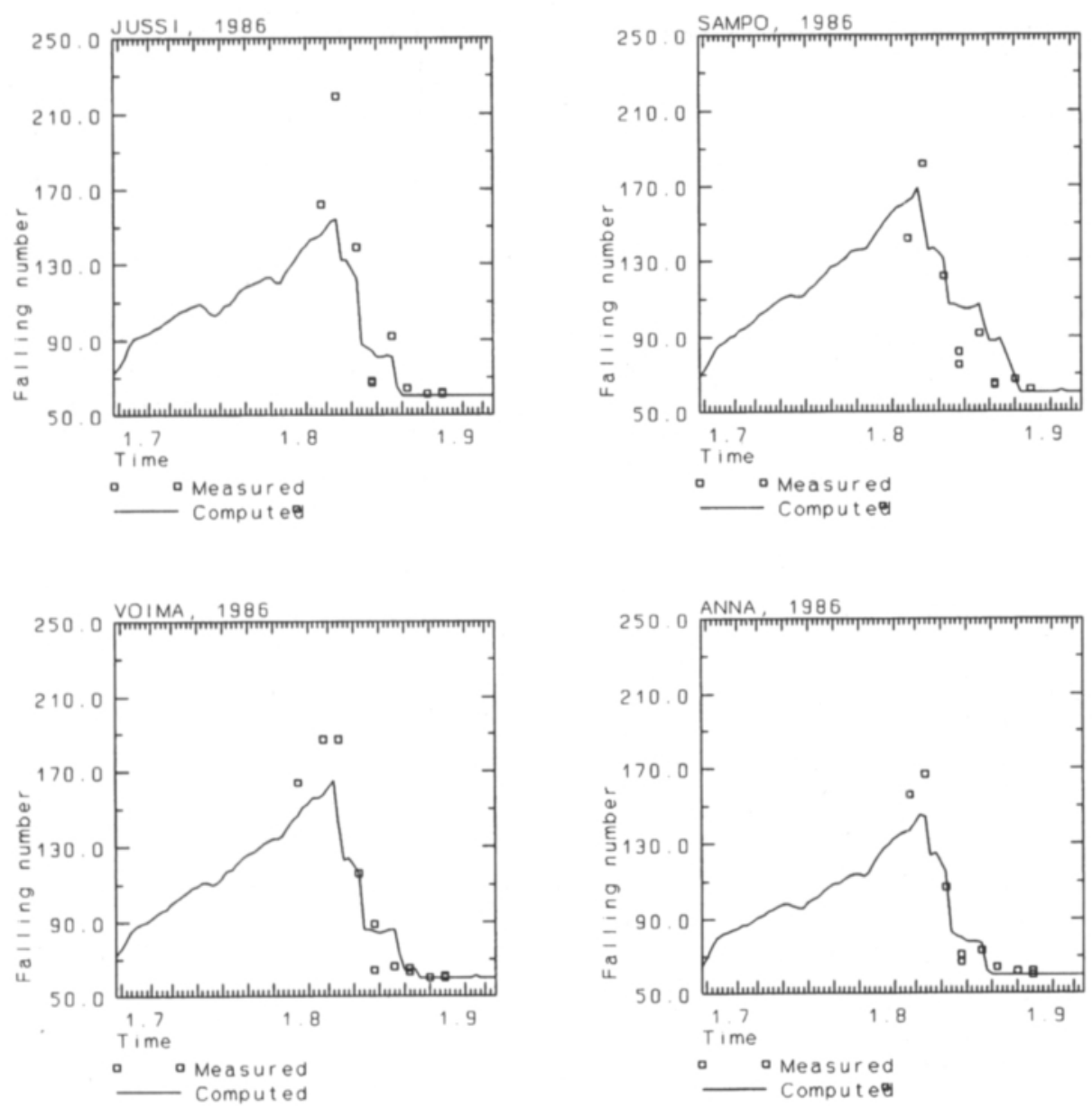

Fig. 8. Measured and computed falling number for year 1986 .

\section{Suggestions to improve the model}

To improve the model, more falling number measurements are needed. These measurements should be started very early when the filling of the kernel starts. It would be useful to make these measurements daily to get more information about the fluctuations of the falling number.

The present version of the model calculates directly the changes in the falling number. However, a more physical structure for the model would be obtained by including the alpha-amylase

activity as an additional dependent variable. Moreover, the computation of the grain moisture content would be useful. In this case the relative humidity of the air must be used as an independent variable.

Another improvement would be to take into account the fact that air temperature affects the influence of precipitation on the decrease in the falling number. If the weather is warm, more precipitation is needed to cause a drop in falling number compared to cool weather. 

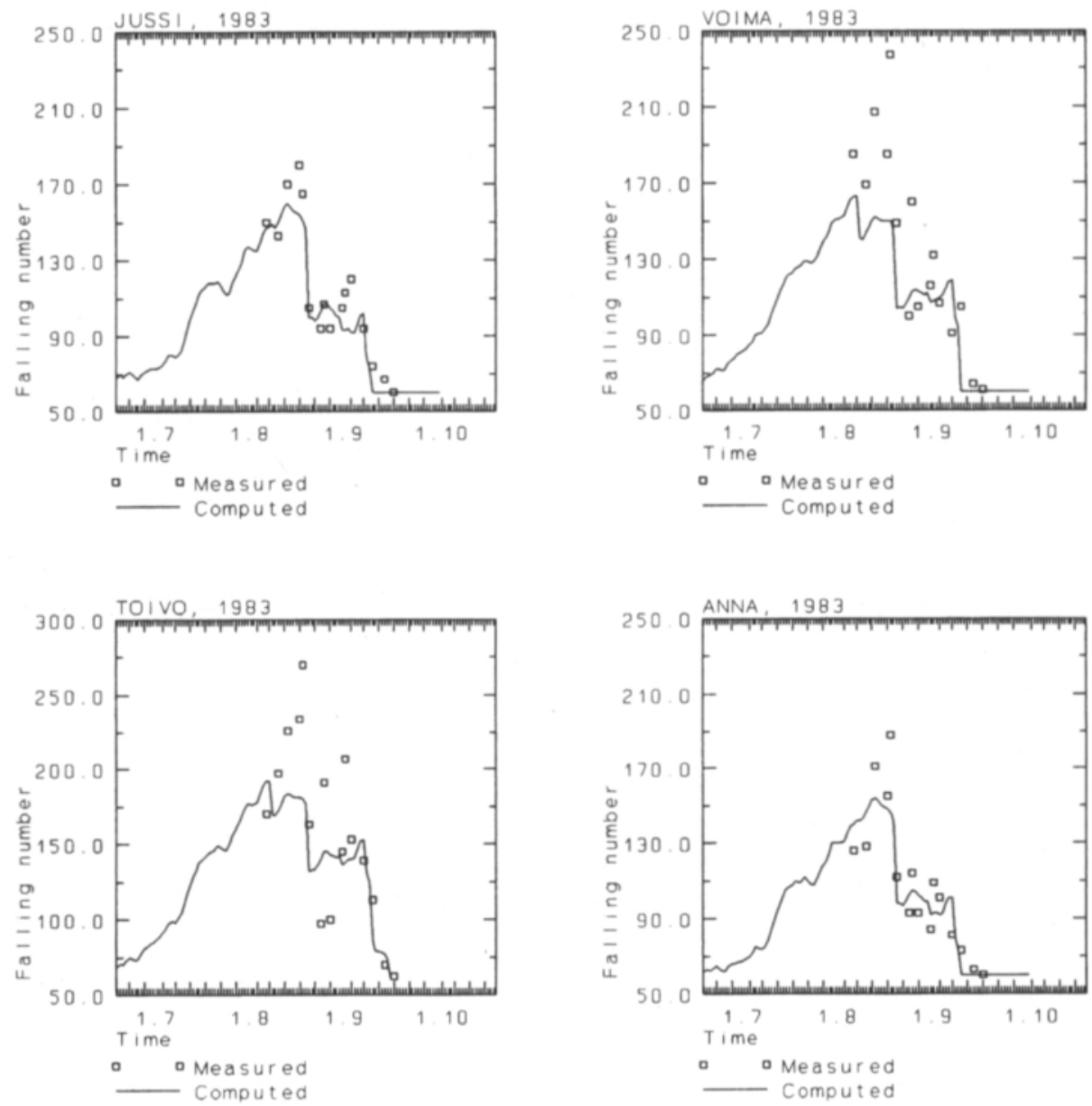

Fig. 9. Measured and computed falling number for year 1983. 

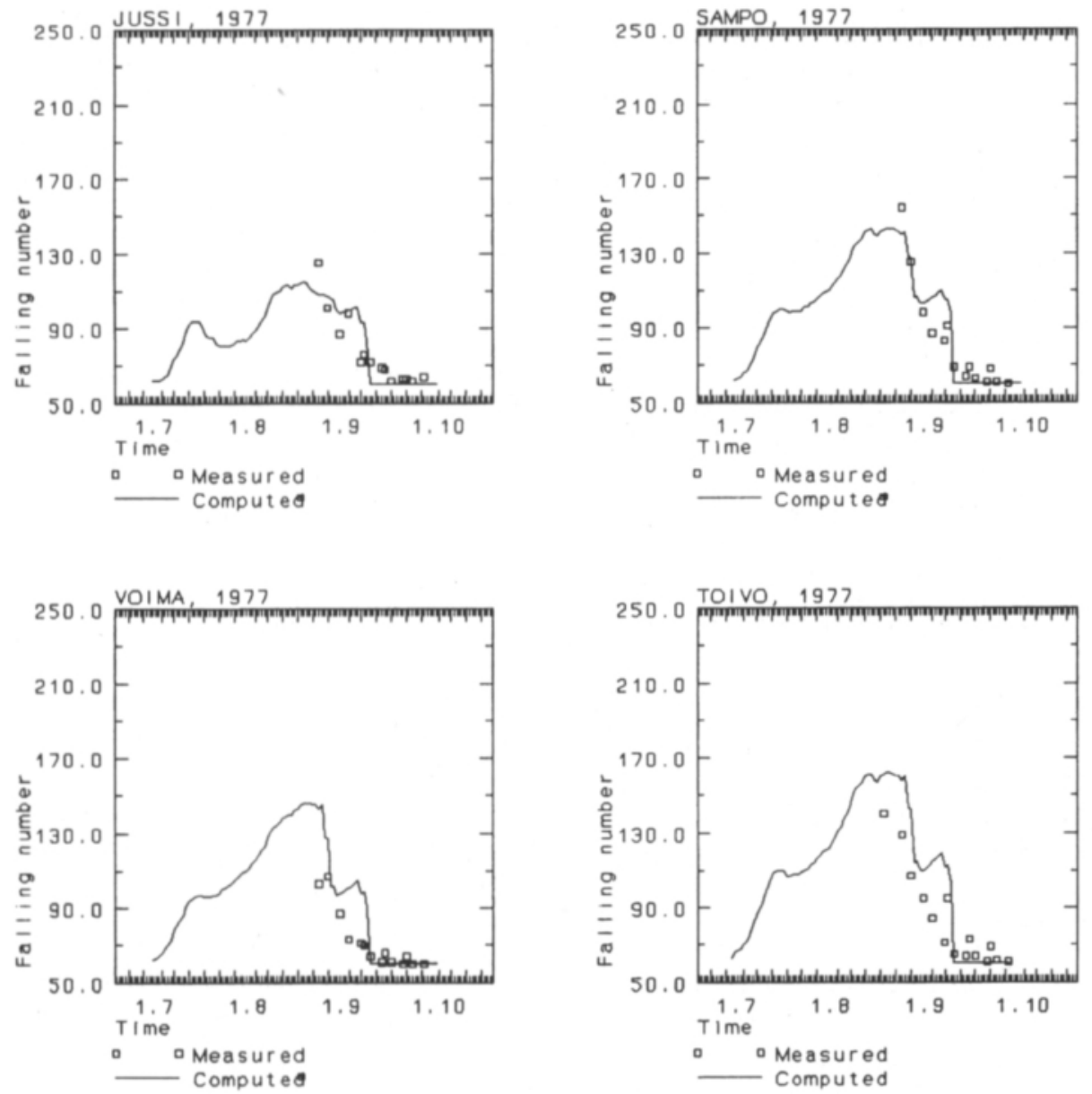

Fig. 10. Measured and computed falling number for year 1977. 


\section{References}

BELDEROK, B. 1968. Seed dormancy problems in cereals. Field Crop Abstr. 21: 203-211.

BENGTSson, A. 1975. Skördetidsförsök med höstråg. Lantbr. högsk. Inst. växtodling Rapp. och Avhandl. 40: 1-27.

FAGERBERG, B. 1966. Falltalets variation med hänsyn till kărnans lăge i axet. Examensarbete i văxtodling. Lantbr. högsk. Uppsala, stencil.

FrÖMAN, B. 1976. Amylasaktivitetens beroende av miljö och odlingsteknik. Lantbr. högsk. Konsulentavd. stencilserie. Mark-Växter 31: 1-56.

HrTZE, W. 1969. Untersuchungen über Aktivităt und Verteilung der -amylase, Cellulase und Proteasen im reifenden Weizen- und Roggenkorn. Berlin.

Hummel-Gumalius, T. 1982. Några văderfaktorers inflytande på falltalet hos Kungsråg i văstra Skåne åren 19651976. Sver. Utsädesför. Tidskr. 3: 203-210.

JUUTI, T. 1985. Syysruis. Hankkijan Siemenjulkaisu 1985: 38-41.

KARVONEN, T. 1990. Automatic parameter estimation using a random search method. Helsinki University of Technology, Laboratory of Hydrology and Water Resources Management, Research Report 1990:6.

KÖYluÄRVI, J. \& SıMOJOKı, P. 1989. Ruis. In: Peltokasvilajikkeet 1989-1990. Maatalouskeskusten Liiton julkaisuja no 772: 14-20.

LALLUKKA, U. 1976. The effect of the temperature during the period prior to ripening on sprouting in the ear in rye and wheat varieties grown in Finland. Cer. Res. Commun. 4: 93-96.

LUNDEGREN, J. 1967. Falltalets variation i odlingar av brödspannmål. Examensarbete i växtodling. Lantbr. högsk. Uppsala, stencil.
OleRED, R. 1963. Enzymuntersuchungen in Weizen und Roggen. Getreide und Mehl 13: 141-144.

- 1967. Development of -amylase and falling number in wheat and rye during ripening. Växtodling 23: 1-106.

- 1976. -Amylase isozymes in cereals and their influence on starch properties. Cer. Res. Commun. 4: 195-199.

— \& HuMmEL-GumÆLius, T. 1966. Falltalsundersökningar på råg och vete under mognadsperioden. Sver. Utsädesför. Tidskr. 76: 177-193.

ROHRLICH, M. \& HitZE, W. 1967. Aktivität und Verteilung der -Amylase in reifenden Weizen und Roggen. Z. Pfl. Zct. 61: 141-158.

VARIS, E., ÖSTERBERG, T. \& HUTtUNEN, R. 1983. Rukiin laadun alueellinen vaihtelu Suomessa. Helsingin yliopisto, kasvinviljelytieteen laitos, julkaisu no 10: 1-47.

Woodman, H.E. \& Engledow, F.L. 1924. A chemical study of the development of the wheat grain. J. Agric. Sci. 14:299-318.

Manuscript received May 1991

Leena Laurila

Tuomo Karvonen

University of Helsinki

Department of Crop Husbandry

SF-00710 Helsinki, Finland

Sirkka-Liisa Hiivola

Agricultural Research Centre of Finland

Research Station of South Ostrobothnia

SF-61400 Ylistaro, Finland 


\title{
SELOSTUS
}

\section{Rukiin sakoluvun ennustaminen dynaamisen mallin avulla}

\author{
Leena Laurila, Tuomo Karvonen ja SirkKa-Liisa Hitvola \\ Helsingin yliopisto ja Maatalouden tutkimuskeskus
}

Tutkimuksen tarkoituksena oli selvittăă rukiin sakoluvun kåyttäytymistä kasvukauden aikana. Pääpaino tarkastelussa oli lămpötilan ja sateen vaikutuksilla.

Tutkimuksen aineisto oli Maatalouden tutkimuskeskuksen Etelä-Pohjanmaan tutkimusasemalta. Aineistona käytettiin rukiin korjuuaikakokeen tuloksia vuosilta 1975-1987. Tåssă kokeessa oli kolme korjuuaikaa. Dynaamisen mallin kehittåmiseksi kåytettiin myös rukiin sakolukupalvelua varten mitattuja sakolukuja. Nämä mittaukset aloitettiin, kun ruis oli maitotuleentumisasteella eli kun rukiin kosteus oli noin $50 \%$.

Săätekijöiden, lämpötilan ja sateen, vaikutusta rukiin sakolukuun tutkittiin dynaamisen mallin avulla. Sen avulla tarkasteltiin viiden lajikkeen sakolukua. Nämä lajikkeet olivat Anna, Hankkijan Jussi, Sampo, Toivo ja Voima.

Dynaaminen malli kykeni parhaiten selittämään Annan sakoluvun kehittymistä, selitysaste oli 0.81 . Heikoimmin malli pystyi selittämään Sampon ja Toivon sakolukua. Molemmille lajikkeille selitysaste oli 0.70 .

Lajikkeiden optimoidut arvot vaihtelivat lajikkeiden ominaisuuksien mukaan. Aikaiset lajikkeet tarvitsivat alhaisemman tehoisan lämpötilasumman saavuttaakseen sen kehitysasteen, jossa jyvă vaipuu itämislepoon. Eri lajikkeiden văliset erot itämislevon pituudessa olivat pienet. Sen sijaan se tehoisa lämpötilasumma, jonka jälkeen itämislepo on päättynyt ja sateen vaikutus sakolukkun alkaa, oli korkein sakoluvunkestävällå Hankkijan Jussilla ja myöhăisillä lajikkeilla. Lämpötilan ja sen vaihteluiden parametrit olivat lähes samansuuntaiset eri lajikkeilla. Esille nousi se seikka, että myőhăiset lajikkeet năyttivăt hyötyvăn muita lajikkeita enemmän todella korkeista läpötiloista. Itämislevon päättymisen jälkeen sadannan vaikutus oli voimakas kaikilla lajikkeilla.

Rukiin sakoluvun maksimi nousi korkealle niină vuosina, jolloin jyvän tuleentumisvaiheessa oli korkeita maksimilämpötiloja. Tåsså tutkimuksessa raja-arvoksi saatiin $23^{\circ} \mathrm{C}$. Näinä vuosina dynaaminen malli ei pystynyt ennustamaan sakoluvun nousua kyllin korkealle. Malli ei myöskään kyennyt ennustamaan sakoluvun vaihteluja kuin osittain.

Jyvän itämislevon päăttymisen jälkeen sakoluku laski nopeasti, erityisesti jos sakoluvun maksimi oli ollut korkea. Laskun aiheuttivat riittävän suuret sateet. Yleensä samaan aikaan sattui myös lämpötilassa selvä lasku tai jopa halloja. Mallin ennustama sakoluvun lasku oli yleensä nopeampi kuin mitatut arvot.

Alhaiset rukiin sakoluvut Etelä-Pohjanmaalla eivăt niinkään johdu sakoluvun maksimin alhaisuudesta, vaan siitä, että rukiin sakoluvun maksimi ajoittuu jyvän maitotuleentumisvaiheeseen. Maksimin saavuttamisen jälkeen sakoluku alkaa laskea sateen ja lämpötilan laskun vuoksi, ja leikkuupuintikuntoisuuden saavuttamiseen mennessä sakoluku on ehtinyt alentua huomattavasti. 